\title{
Invasive alien plants occurring in Lesotho: Their ethnobotany, potential risks, distribution and origin
}

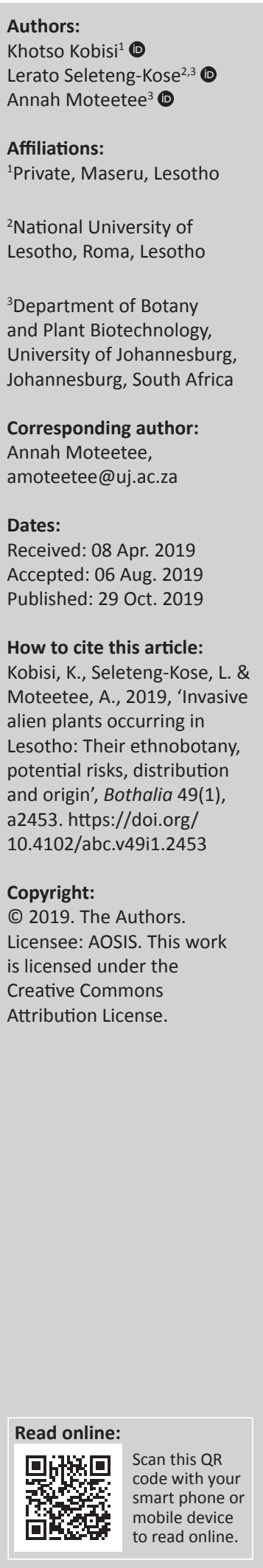

Background: Several recent studies have documented the ethnobotanical uses of plants used in Lesotho, in particular those used for medicinal purposes. However, these reports did not make a distinction between indigenous, naturalised or invasive alien plants. Furthermore, the existing records on the status of the occurrence of these plants in the country are not up to date.

Objectives: The aim of this article is to present information on the current knowledge regarding the status of invasive alien plant species in Lesotho and to discuss their ethnobotanical uses, distribution in the country, origin and safety. We further assess the existing legislation designed to regulate the spread of such plants and make a comparison with the invasiveness and regulation of such plants in the neighbouring South Africa.

Method: This article is based mainly on a literature survey of published information obtained from various databases, such as Google Scholar, Science Direct and Scopus, as well as from unpublished data such as technical reports, dissertations and theses.

Results: A total of 57 species, comprising one pteridophyte, one gymnosperm and 56 flowering plants (52 dicotyledons and 4 monocotyledons) are documented. Although these plants are invasive in nature, they are utilised for a variety of purposes including food, treatment of various medical conditions, cosmetics and functional uses. However, some of the species are reported to be poisonous to both animals and humans, with a majority of the plants causing skin irritation. Most of these species are widely distributed throughout the country and most of them originated from America, Europe and Asia. Although a number of reports on the occurrence of invasive alien plants have been generated, the information therein has not yet been published.

Conclusion: This study has identified knowledge gaps in terms of safety and distribution of the species, as well as shortfalls in the policies intended to regulate invasive alien species (IAS) in Lesotho. Further research in this regard is therefore recommended.

Keywords: biodiversity decline; control measures; encroachment; legislation; naturalised.

\section{Introduction}

The past ten years have seen an increase in the number of studies documenting the ethnobotanical and/or ethnomedicinal uses of plants in Lesotho, either in the form of literature reviews (e.g. Moteetee, Moffett \& Seleteng-Kose 2019; Moteetee \& Seleteng-Kose 2017; Moteetee \& Van Wyk 2011) or in the form of ethnobotanical surveys based on questionnaires (e.g. Mugomeri, Chatanga \& Chakane 2016a; Mugomeri et al. 2016b; Seleteng-Kose, Moteetee \& Van Vuuren 2015). All of these studies concluded that numerous plants are used for several ethnobotanical purposes, including food, medicine and other functional uses such as furniture and building. However, these studies did not make any distinction between indigenous, naturalised or alien (and invasive) species. A few papers have documented the traditional uses, in particular medicinal uses, of invasive alien plants (IAPs) in other regions, for example in Limpopo province of South Africa (Maema, Potgieter \& Mahlo 2016) and Bangladesh (Khan et al. 2011; Rahman \& Roy 2014).

Pyšek et al. (2004:136) have proposed standardised terminology to be used in invasion biology and provide a definition of invasive plants as naturalised plants that produce reproductive offspring, often in large numbers, at considerable distances from the parent plants, and thus have a potential to spread over a large area'. The authors define 'alien plants' as those that have been deliberately or unintentionally introduced into an area because of human activity, or 'which have arrived there without the help of people from an area in which they are alien'. According to the Department of Environmental Affairs (2014), there is increased extinction of indigenous medicinal 
plants as well as a decline in biodiversity; on the other hand, there have been increased incidences of invasive alien species (IAS). The increase of alien plants has resulted in serious economic impacts worldwide (Vilà et al. 2011). For example, according to Bromilow (2010), IAS cause a wide range of destructive consequences, which include a decline in species diversity, local and total extinction of indigenous species, ecological imbalance, increased fire hazard, decreased productivity of rangelands and reduction in land value. In addition, IAS are reported to cause reduction in conservation and tourism value, soil erosion and the consequent siltation of dams and rivers, depletion of water resources, changes in the natural soil composition and oxygen depletion in water (Bromilow 2010).

Lesotho, like many other countries, has witnessed an increase in the encroachment of invasive plants because of, among others, overgrazing, changing fire regimes, as well as climate change (Hae 2016). Climate change is especially critical because it 'facilitates the spread and establishment of many alien species and creates new opportunities for them to become invasive' (IUCN 2017). Despite their negative impacts, some IAPs were introduced with good intentions. For example, as Lesotho is one of the least forested countries in Africa (Chakela 1999), tree species such as Acacia dealbata, Populus x canescens (Aiton) Sm., as well as Pinus L. and Eucalyptus L'Hér species were introduced for soil conservation measures, provision of fuel wood and as valuable forms of biomass (NES 2000). However, the latter two are reported to use greater amounts of water than the natural vegetation. This has led to depletion of the underground water, hence posing a threat to the ecosystem functioning (NES 2002, 2005). In addition, aquatic plant invaders pose serious threats to waterbodies, for example common aquarium plants such as Parrot's Feather (Myriophyllum aquaticum (Vell.) Verdc. and the Red Water Fern (Azolla filiculoides (Lam.) that have invaded several dams in the country (NES 2000).

There are limited publications on the invasive alien plants of Lesotho; so far the only published information on the invasive alien plants of Lesotho has emanated from research conducted as part of regional studies, in particular South African projects, such as Kotze et al. (2010), focusing on the national invasive alien plant survey. Other publications include the pioneering work of roadside surveys of invasive plants in South Africa by Henderson (1989, 1991a, b, 1992, 1998a), as well as Bromilow (2010), Nel et al. (2004) and Rouget et al. (2004). Bromilow (2010) focused on problem plants and alien weeds of South Africa including Lesotho and Eswatini (previously Swaziland). A few specific studies on Lesotho IAS were undertaken by the National Environment Secretariat (NES 2005 2007). Other earlier technical reports by NES $(2000,2002)$ gave limited information on IAS. These reports have however not been published, are outdated and in some cases inaccurate. For example, according to NES (2002), some plant species such as Acacia saligna (Labill.) H.L.Wendl. and Hakea sericea Schrad. \& J.C. Wendl. have dominated some areas to the extent that natural vegetation has been lost completely. However, based on previous publications (e.g. Jacot Guillarmod 1971; Kobisi 2005; Phillips 1917), there is no evidence that these two species ever occurred in Lesotho. This is possibly a case of mistaken identity; nonetheless, the situation is true for other species such as Acacia dealbata Link. (pers. obs.).

Henderson's studies culminated in the launch of the Southern African Plant Invaders Atlas (SAPIA) project, which included South Africa, Lesotho and Eswatini (Henderson 1998b). The objective of the project was to 'collate information on the distribution, abundance, and habitat types of invasive and naturalized alien plants' (Henderson 2007:215). Nel et al. (2004) proposed a classification of invasive alien plant species for South Africa, Lesotho and Eswatini into three categories: those already widespread, those that have recently started to invade and those that are not yet invasive. Rouget et al. (2004) evaluated the correlation between climate and distribution of 71 important IAPs, and an analysis of potential implications of these results for future spread of the invaders in different vegetation types of South Africa, Lesotho and Eswatini. In 2005, NES published the first assessment of the status of IAS in Lesotho (NES 2005), giving aspects of their origin, geographical spread, uses, impacts and control measures in the country, although the geographical spread of species was 'based on observation rather than survey and related mapping of IAS' (NES 2005). Even though not published, these technical reports serve as a good foundation for the development of research activities covering several aspects of biological invasions, including their taxonomy, ecology, ethnobotany and ethnopharmacology, etc.

This study is a review of the current knowledge regarding the status of the occurrence of invasive alien plants in Lesotho, as well as their ethnobotanical uses, distribution in the country, origin and safety. The study also reviews the present legislations and policies that deal specifically with the regulation of IAPs in that country.

\section{Methodology}

This study is based on extensive consultation of literature resources and it integrates data from these unpublished lists as well as published work on IAPs in Lesotho and the surrounding South Africa, which have similar vegetation. Regional publications used to search for Lesotho records include Henderson (1989, 1991a, b, 1992, 1998a, b, 2007). In addition, the publications on invasive alien plants for South Africa, Lesotho and Eswatini by $\mathrm{Nel}$ et al. (2004) as well as Problem Plants and Alien Weeds of South Africa by Bromilow (2010) were consulted. A search on the Plants of Southern Africa website (https://newposa.sanbi.org) was also undertaken. Technical reports of studies specific to IAS in Lesotho by the National Environment Secretariat were also utilised, namely NES (2005, 2007). Other earlier technical reports, which incorporated IAS in Lesotho, were also used, namely the Biological Diversity Report (NES 2000) and State of Environment Report (NES 2002). In addition, Google, Google Scholar, Science Direct, iSpot and iNaturalist (https://www.inaturalist.org/ check_lists /9173-Lesotho-Check-List?iconic_taxon=47126) 
were also used. Data were supplemented by examination of specimens located in the National University of Lesotho herbarium (ROML) as well as personal observations in the field (although not comprehensive), as shown in Table 1. As a result, a revised list was compiled updating the nomenclature using The Plant List, 2013, Version 1.1, Published on the Internet, from http://www.theplantlist.org/ and rectifying wrong records.

\section{Ethical consideration}

This article followed all ethical standards for research without direct contact with human or animal subjects.

\section{Results and discussion Species diversity}

A list of invasive alien plant species occurring in Lesotho is presented in Table 1. Author citations are provided here and will not be repeated henceforth. A wide range of ethnobotanical uses of the IAPs is provided, ranging from food, fodder, through firewood, building material and timber production, to medicine and pesticides. In addition, information on their distribution and origin, as well as potential risks, is also given. In its report, NES (2005) documented a total of 31 invasive aliens comprising 15 trees and shrubs, 12 herbaceous and succulent weeds, 3 aquatic weeds and 1 grass species. A more comprehensive evaluation, produced 2 years later (NES 2007), listed a total of 54 invasive alien plant species (51 terrestrial and 3 aquatic) representing 25 families of angiosperms and 1 pteridophyte, with the largest number of species recorded in Asteraceae (7) followed by Cactaceae (5). That study also added information about species habitats, uses, distribution maps, pathways of introduction and invasive traits to the previous data. In the current study, a total of 58 species is recorded, comprising 1 pteridophyte, 1 gymnosperm and 56 flowering plants (52 dicotyledons and 4 monocotyledons). These numbers exclude 11 species (marked with $\dagger$ in Table 1) not listed by NES (2007) as invasive, but warrant further analyses to determine their status in the country (as discussed in subsequent sections). The largest number of species is recorded in the family Asteraceae (9), followed by Fabaceae (7) and Cactaceae (6). This is not surprising as Asteraceae is the largest flowering plant family, while Fabaceae is the third largest.

As Lesotho is completely surrounded by South Africa, we make a comparison with neighbouring areas of South Africa with regard to status, occurrence and distribution patterns of IAPs, particularly because 'invasiveness elsewhere is one of the most reliable indicators of invasion risk' (Early et al. 2016:5). To this end, it is important to note that nine species recorded by NES (2007) as IAS in Lesotho are not declared as such by the National Environmental Management: Biodiversity Act (No. 10 of 2004) (NEMBA) (https://invasives.org.za/ legislation/what-does-the-law-say) in South Africa (highlighted in bold in Table 1). These are Avena fatua, Cosmos bipinnatus, Erigeron bonariensis, E. canadensis, E. sumatrensis,
Foeniculum vulgare, Glandularia aristigera, Polygonum aviculare and Populus nigra var. italica. However, it is possible for a species to be invasive in one ecosystem but not in another. On the other hand, 11 other species (Acacia baileyana, Agrimonia procera, Eucalyptus camaldulensis, Hypericum perforatum, Ligustrum japonicum, L. lucidum, Morus alba, Pennisetum villosum, Sorghum halepense, Verbena brasiliensis and $V$. rigida) known to occur in Lesotho, and reported to be invasive in South Africa (https://invasives.org.za/ resources/national-status-reports), are not recorded as invasive in Lesotho. However, it is important to note that South Africa is much larger and more diverse than Lesotho, with many different ecological conditions such as habitats, climate zones, soil types, etc., which may be suitable for the plants to become invasive. A search on the Plants of Southern Africa website (https://newposa.sanbi.org) for occurrence records of these plants in Lesotho returned the following results (number of specimens shown in brackets): A. baileyana (0), Agrimonia procera (1), H. perforatum (1), L. japonicum (0), L. Iucidum (0), M. alba (0), P. villosum (1), S. halepense (3), $V$. brasiliensis (3) and $V$. rigida (3). A preliminary checklist of Lesotho plants (Kobisi 2005) listed all these species, with an exception of L. japonicum, as occurring in Lesotho. According to Henderson (2001), there were some records for A. baileyana, $H$. perforatum, the two species of Ligustrum and M. alba, while there were none for P. villosum and S. halepense occurring in Lesotho. Although Bromilow (2010) cautions that the distribution maps provided in his book are not a 'definitive indication of the actual distribution of a plant', his maps suggest that all these species (with the exception of $H$. perforatum) do occur in Lesotho. Of these species, the National University of Lesotho herbarium (ROML) has collections of only $S$. halepense and V. brasiliensis; however this should not be seen as an indication that the other species do not occur in the country, and it is possible that the country is underreported. The existence of these species in Lesotho and their invasive status in South Africa may not necessarily suggest that they are invasive in Lesotho; however, these conflicting distribution records have revealed the dire need for a detailed assessment of their potential invasiveness or invasive status in Lesotho. It is surprising to note that NES (2007) did not list E. camaldulensis as an invasive plant in Lesotho, although this plant occurs widely in the country. The reason for this could be that the plant is naturalised in the country and considered by most people to be a very useful naturalised plant, instead of an IAP. A more detailed assessment is required to determine whether the distribution of E. camaldulensis fits Pyšek et al.'s (2004) definition of naturalised plants.

\section{Ethnobotanical uses}

Despite being invasive, some of the plant species are utilised for a variety of purposes ranging from food (vegetables, fruits), medical conditions (skin, reproductive, digestive and respiratory problems) to functional uses such as building, poles, rafters, firewood and sleighs. For example, Nasturtium officinale and Hypochaeris radicata are consumed as leafy vegetables, whereas Opuntia ficus-indica, Gleditsia triacanthos, Pyracantha angustifolia, Rosa rubiginosa and Rubus cuneifolius are consumed for their edible fruits, with the last two species 


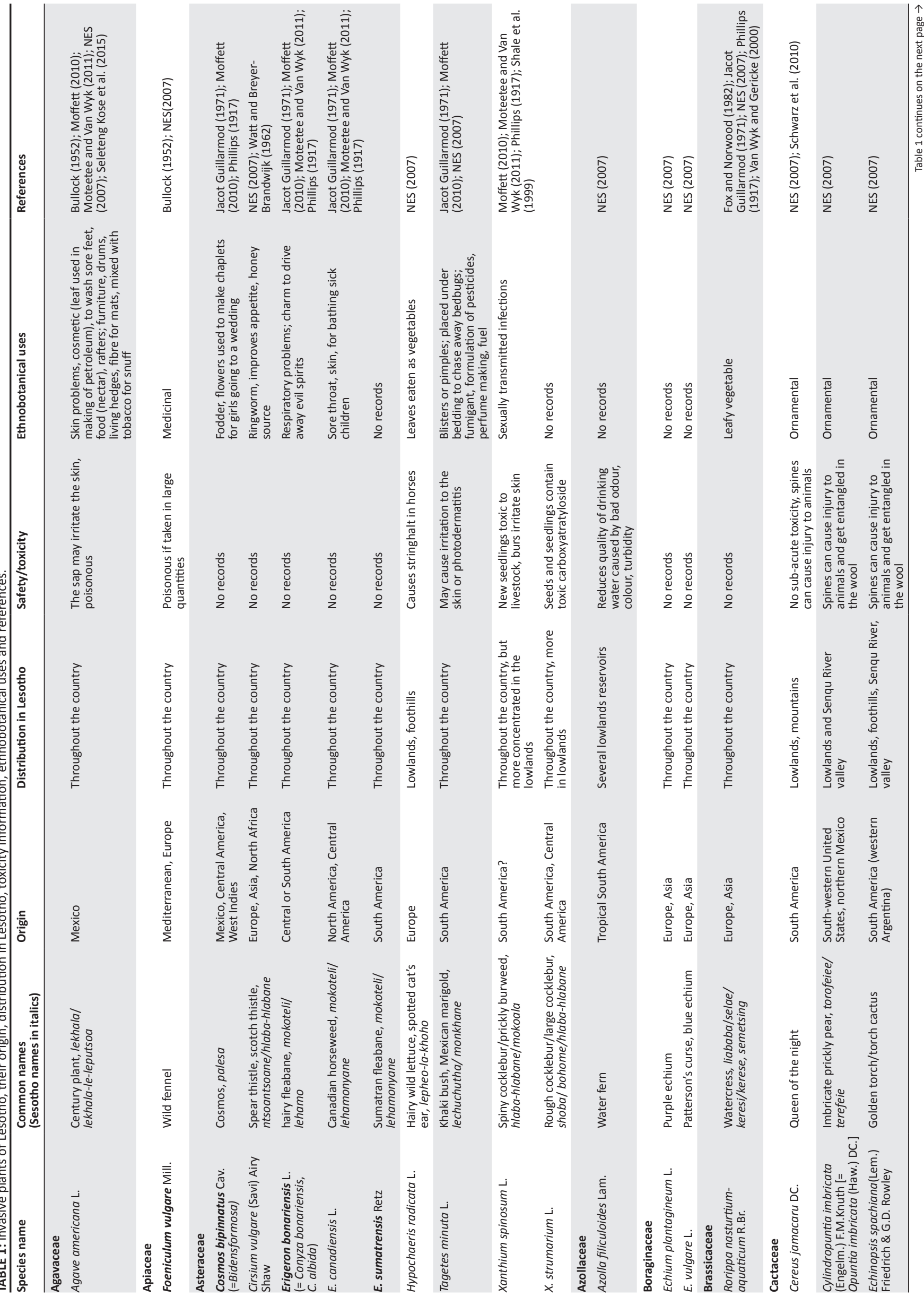




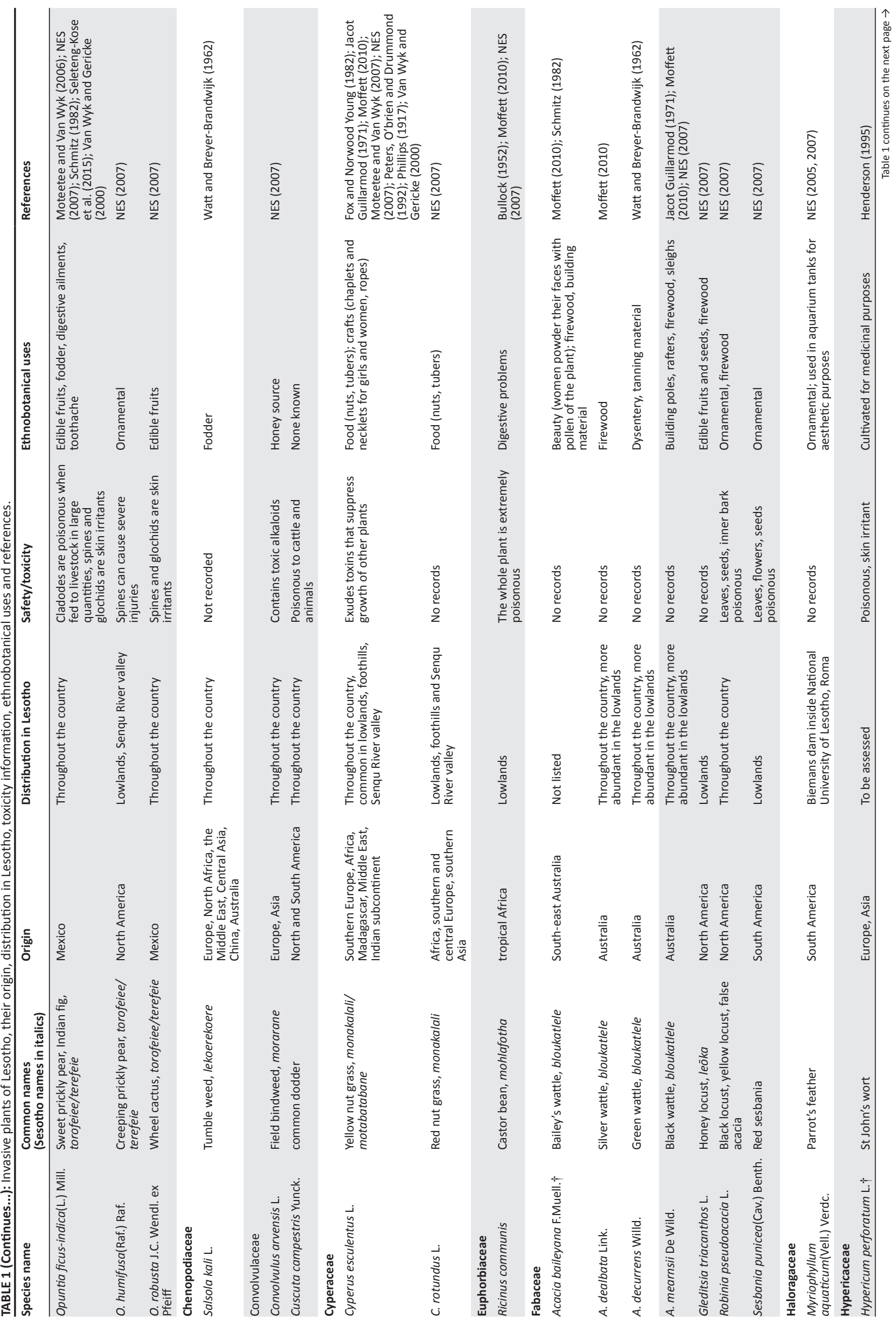




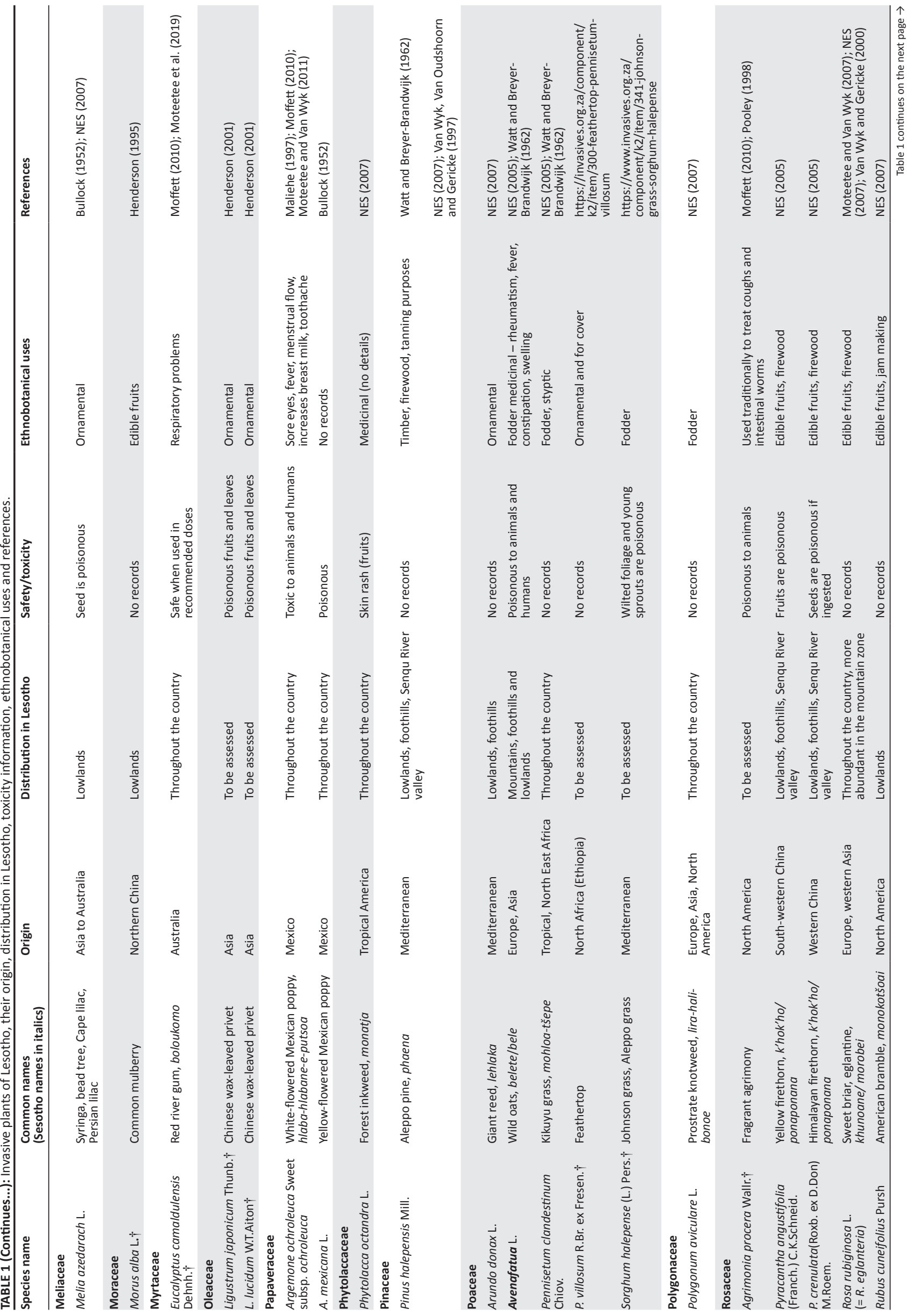




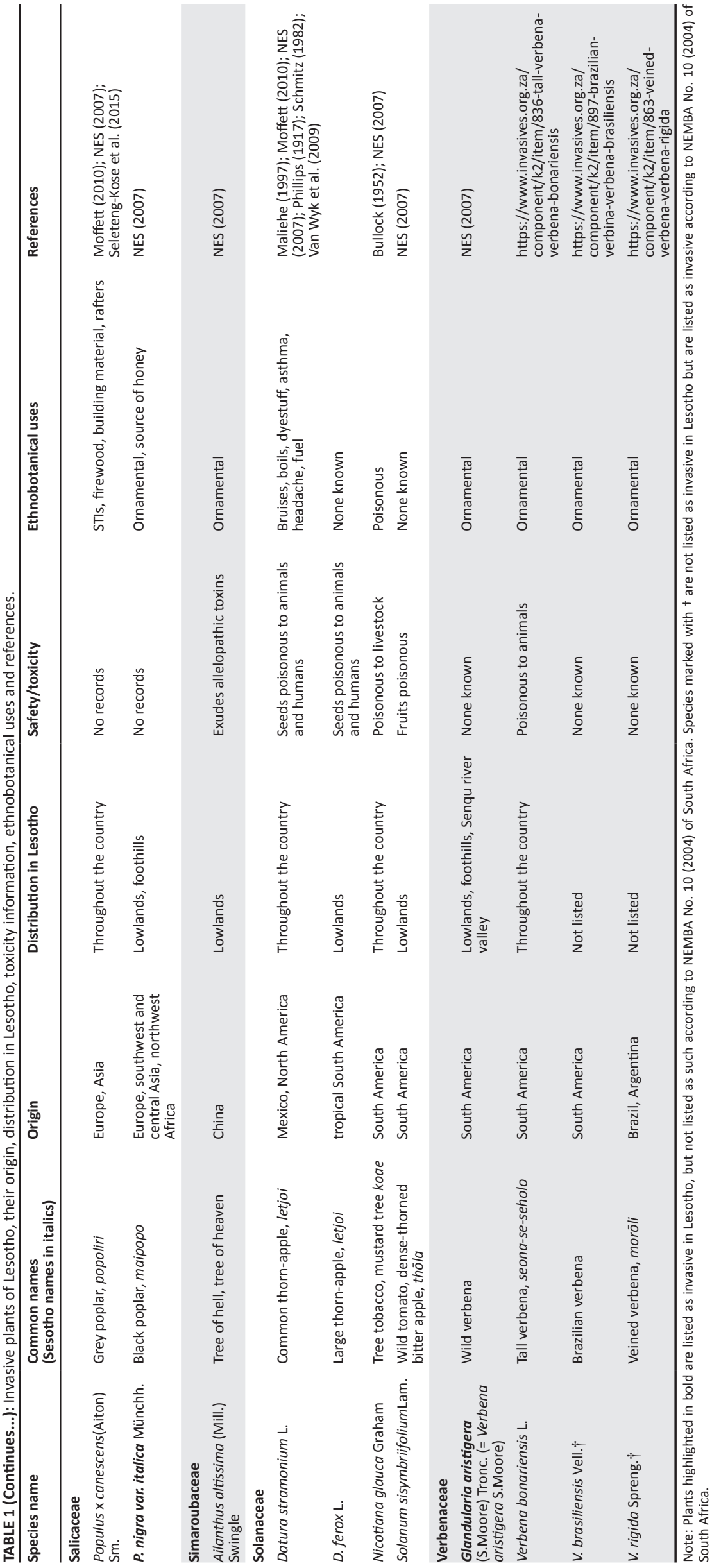


also used in jam making. In addition, Convolvulus arvensis is used by bees for producing honey. Animal feeds include such species as O. ficus-indica, Pennisetum clandestinum, Salsola kali and S. halepense. The tubers of Cyperus esculentus are eaten raw or roasted (pers. obs.).

A total of 17 species is used for medicinal purposes. Four of these (Agave americana, Datura stramonium, S. halepense and Tagetes minuta) are used for a variety of skin problems, namely bruises, blisters, sore feet, pimples, swelling and boils (Jacot Guillarmod 1971; Moffett 2010; Moteetee \& Van Wyk 2011; NES 2007; Seleteng-Kose et al. 2015). Interestingly, the leaves of $A$. americana are used in the making of petroleum jelly in Lesotho. Other plants of medicinal importance include those used in the treatment of digestive ailments such as dysentery and constipation, and these include: A. dealbata (Moffett 2010), A. mearnsii De Wild. (Jacot Guillarmod 1971; Moffett 2010; NES 2007), O. ficus-indica (Moteetee \& Van Wyk 2006; NES 2007; Schmitz 1982; SeletengKose et al. 2015; Van Wyk \& Gericke 2000) and S. halepense (http:/ / www.invasives.org.za/component/k2/item/341johnson-grass-sorghum-halepense). Three species (Argemone ochroleuca Sweet, S. halepense and D. stramonium) are used for respiratory ailments, including asthma and fever. Moreover, D. stramonium is also used to treat headache (Maliehe 1997; Moffett 2010; NES 2007; Phillips 1917; Schmitz 1982; Van Wyk, Van Oudtshoorn \& Gericke 2009). Three species are used for the treatment of reproductive problems: Xanthium spinosum (Moffett 2010; Moteetee \& Van Wyk 2011; Phillips 1917; Shale, Stirk \& Van Staden 1999) and Populus x canescens (Moffett 2010; NES 2007; Seleteng-Kose et al. 2015) are used specifically for sexually transmitted infections (STIs) and A. ochroleuca is used by women for controlling menstrual flow and increasing breast milk. In addition, A. ochroleuca is utilised for the treatment of sore eyes (Maliehe 1997; Moffett 2010; Moteetee \& Van Wyk 2011). Other medicinally important species include $S$. halepense, which is used for the treatment of rheumatism, and A. americana and T. minuta, which are ground into powder and taken as snuff (Jacot Guillarmod 1971; Moffett 2010; Moteetee \& Van Wyk 2011; Seleteng-Kose et al. 2015).

Functional uses (such as poles, rafters, hedges and sleighs) are observed in several Acacia species, such as A. dealbata, A. decurrens, A. mearnsi, as well as Populus x canescens and A. americana. Leaves of $A$. americana are also used to make fibres used in floor mats (Moteetee et al. 2019). The importance of trees such as A. decurrens and Pinus halepensis Mill. as sources of firewood is highly significant in remote areas where electricity and other sources of fuel are scarce. Other species used for making fire include D. stramonium, G. triacanthos, $P$. angustifolia, $R$. rubiginosa and T. minuta. Some species are used as ornaments, namely Ailanthus altissima, Arundo donax, Cereus jamacaru, Echinopsis spachiana, G. triacanthos, Melia azedarach, M. aquaticum, O. humifusa and Robinia pseudoacacia. Women and girls use C. esculentus for making chaplets and necklets. In addition, they use pollen from A. baileyana as powder. Other useful species include T. minuta, which is used as a fumigant and in the formulation of pesticides as well as perfume. In addition, it is placed under bedding to deter bed bugs. Nicotiana glauca is used as a rat or cockroach poison, whereas M. aquaticum is used in aquarium tanks for aesthetic purposes. Many of the plants (18 in total) are used for ornamental purposes. Interestingly, in a study by Weber, Sun and Li (2008), the use of AIPs for ornamental purposes in China was identified as the most frequent economic use, with medicinal uses second. This seems to be the case for Lesotho as well.

On the other hand, some of the IAPs seem to be making notable impact in the commercial arena, for example $A$. americana and $R$. rubiginosa have entered local and international biotrade industries for making useful products for the food, pharmaceutical and cosmetic industries (Department of Environment 2014). In fact, Lesotho is currently exporting $R$. rubiginosa fruits to Germany (through the Rosehip Company) for making tea and jam, as well as for the production of essential oils used in the cosmetics industry. In addition, the remaining residue is reported to induce fertility in animals. To this end, it is projected that by 2040 the country may witness depleting number and abundance of commercially useful native species and increasing number and abundance of commercially used IAS (Department of Environment 2014).

\section{Origin and distribution}

A majority of the plants have originated from Europe (16), the Americas (North America = 8; Central and South America = 20) and Asia (16), with a few species from the rest of Africa (8) and China (Northern, Western) (5). Lesotho is divided into four agro-ecological zones, namely Lowlands, Foothills, Mountains and Senqu Valley, most of the recorded species have spread throughout the country across the four zones. The plants include Acacia species, A. americana, A. ochroleuca subsp. ochroleuca, Cirsium vulgare, Populus x canescens and R. rubiginosa. It is worth noting that an estimation of IAP infestation for Lesotho by Kotze et al. (2004) showed that most parts of the country, including all the four zones, have infestations $\geq 40 \%$. On the other hand, a limited number of species are confined to specific zones because of varying altitudinal and climatic preferences which are different in the four zones. For example, A. filiculoides, G. triacanthos, $M$. azedarach and $P$. halepensis are confined to the lowlands, which is characterised by warmer temperatures and low altitude (below 1820 m.a.s.l.). However, the distribution of C. esculentus, E. spachiana, Cylindropuntia imbricata and $H$. radicata also extends to the Foothills and Senqu Valley, with the former having altitude of more than 1820 m.a.s.l. and the latter being the most degraded and driest zone. Only one species, C. jamacaru, is confined to the mountain zone; it is worth noting that in its natural habitat in eastern and north-eastern Brazil, the species occurs in dry, open forest areas and prefers less dry areas (Tropical Plants Database, Ken Fern. tropical.theferns.info.; tropical.theferns.info/ viewtropical.php?id=Cereus+jamacaru). 


\section{Potential risks}

Some of the plants are reported to be unsafe. For example, the fruits of $P$. octandra are said to be poisonous and capable of causing skin irritation, T. minuta causes irritation of the skin or photodermatitis yet it is used as a snuff (Jacot Guillarmod 1971), Ricinus communis and Sesbania punicea are extremely poisonous and the seeds are lethal. In fact, $R$. communis is regarded as the most poisonous plant for humans in the world, although it is used for medicinal purposes in many parts of Africa (Kuete 2014). In addition, A. ochroleuca subsp. ochroleuca is reported to be poisonous and an irritant, while the seeds can contaminate sheep's wool (Bosch 2007). Although O. indica has many uses, the cladodes are reported to be poisonous when fed to livestock in large quantities. Young seedlings of X. spinosum and X. strumarium are toxic to livestock and burs may irritate the skin. Similarly, $R$. pseudoacacia (leaves, seeds and inner back) and D. stramonium (seeds) are poisonous to both animals and humans (NES 2007). Species of Datura including D. stramonium are used as narcotics in many parts of the world (https:/ / www.cabi.org/ ISC/datasheet/18006).

\section{Control}

If properly planned and executed, many IAPs can be controlled through three primary methods of control: mechanical, chemical or biological. However, we are not aware of any control or eradication programmes in Lesotho, and we are also not aware of any early detection programmes. Mechanical methods may include physical removal of rhizomes, roots, cultivation and repeated cutting of the stem (Bromilow 2010). The removal can be done by hand-pulling, using hand-held tools or even bulldozers, and can be done in combination with burning (Van Wilgen et al. 2001). However, many species are difficult to control because they have extensive underground systems and produce large quantities of seeds and therefore regenerate vigorously. Furthermore, if the area is heavily invaded, mechanical controls can be laborious and therefore costly. Other mechanical methods include ring-barking (which can be used to kill large trees such as Populus x canescens) as well as cut-stumping and frilling of small trees such as A. altissima and $R$. pseudoacacia. In the case of trees, these methods should be followed by an application of herbicides as unremoved fragments may re-sprout and grow after the initial cutting. Herbicides can also be applied to kill seedlings of targeted IAPs, for example D. stramonium is susceptible to a wide range of herbicides that can be applied to the soil or leaves, including acifluorfen, bentazone, atrazine, cyanazine, simazine, bromoxynil, metolachlor and 2,4-D (https://www.cabi.org/ISC/datasheet/18006). However, there are concerns regarding the use of herbicides because of their negative impact on the environment (Van Wilgen et al. 2001). Biological control is preferred over mechanical and chemical controls as it is regarded to be more cost-effective and safer. In South Africa, the programme goes as far back as 1913 and since then 63 control agents have been successfully released (Zimmerman, Moran \& Hoffman 2004).
For example, the release of the mealybug (Hypogeococcus pungens Granara de Willink) is reported to have been successful in curbing the spread of C. jamacaru across most parts of the country (Paterson et al. 2011).

Legal instruments have also been instituted to control and eradicate invasive species in Lesotho, namely Laws of Lerotholi (1959), Weeds Eradication Act 18 of 1969, as well as the Environmental Act (2001). However, the biggest challenge is the establishment of prevention programmes for minimising further damage of ecosystems by IAPs. Several initiatives have been undertaken, such as manual removal of the species in some areas. Although the Lesotho Environment Act of 2001 prohibits the introduction of invasive alien species into ecosystems, 'there are no provisions for the necessary instruments to prevent introductions, spread and management of invasions, both for alien and indigenous species' (NES 2007). Furthermore, unlike in the neighbouring South Africa, where a national strategy for dealing with biological invasions has been developed (National Strategy 2014), no such legislation or guidelines exist in Lesotho. In addition, there is no national list of invasive species or their categorisation based on their level of impact or risk as is the case for South Africa (http://invasives.org.za/resources/ national-status-reports).

According to Shackleton et al. (2007), the reliance on IAS by rural livelihoods is often not considered when control measures are put in place. While we did not consider the possible effects of the regulation and/or eradication of IAPs to the livelihoods of the rural communities in the current study, it can be inferred from the previous sections that despite the invasive nature of these plants, many of them have numerous uses in Lesotho. In a country with high unemployment rates between $24 \%$ and $28 \%$ and $53.7 \%$ of the population living below the poverty line (https:/ / www.worldbank.org/en/country/lesotho/overview), the importance of these plants cannot be overemphasised. For example, we (all three authors) have personally observed scores of people (both men and women, young and old) collecting bucket loads of $R$. rubiginosa fruits, most likely to supply the export market. In this instance, the resource use benefit could outweigh its threat to biodiversity and the ecosystem; however, this warrants a more detailed analysis.

\section{Conclusions}

Several efforts have been made to assess and record occurrence of IAS in Lesotho; however, several gaps have been identified. The current study builds on the previous reports with the purpose of extensively documenting species that have been introduced into the country and have spread displacing indigenous species. Although this study recorded only four more IAPs than the previous study (58 vs. 54), the uncertain invasive status of 11 other species has been identified. However, 10 of the recorded species are reported as invasive in Lesotho but are not regarded as such in South Africa. Information on origin, distribution in 
Lesotho, potential risks and ethnobotanical uses of the documented IAPs has also been recorded. Interestingly, many of these IAPs have a wide range of ethnobotanical uses, such as food and medicine as well as functional uses such as building, poles, rafters, firewood and sleighs, despite some of them being toxic to both humans and animals. In fact some of the species such as $R$. rubiginosa have entered international trade, being exported to Germany for manufacturing of products in the pharmaceutical and cosmetic industries. Unfortunately, the current legislation relating to the prevention and management of the spread of IAPs is inadequate and does not provide appropriate guidelines and implementation strategies. A concerted effort is also required from scientists to conduct comprehensive and multidisciplinary research on biological invasions in Lesotho in order to influence policymaking; however, this will require a strong political will and substantial amounts of funding.

\section{Acknowledgements}

The authors are grateful to the University of Johannesburg for the financial and logistical support. L.S.-K. thanks the National University of Lesotho for logistical support.

\section{Competing interests}

The authors declare that they have no financial or personal relationships that may have inappropriately influenced them in writing this article.

\section{Authors' contributions}

A.M. conceptualised the research project, L.S.-K. compiled the original manuscript and K.K. compiled the list of alien invasive plant species. All authors contributed equally to the editing of the manuscript.

\section{Funding}

This research was funded by the University of Johannesburg.

\section{Data availability statement}

Data sharing is not applicable to this article as no new data were created or analysed in this study.

\section{Disclaimer}

The views and opinions expressed in this article are those of the authors and do not necessarily reflect the official policy or position of any affiliated agency of the authors.

\section{References}

Bosch, C.H., 2007, 'Argemone mexicana L', in G.H. Schmelzer \& A. Gurib-Fakim (eds.) Prota 11(1): Medicinal plants/Plantesmedicinales 1, pp. 116-119, CD-ROM, PROTA, Wageningen

Bromilow, C., 2010, Problem plants and alien weeds of South Africa, Briza Publications, Pretoria.

Bullock, A.A., 1952, 'South African poisonous plants', Kew Bulletin 7(1), 117-129.
Chakela, Q.K. (ed.), 1999, State of the Environment in Lesotho 1997, National Environment Secretariat, Maseru.

Department of Environment, 2014, Lesotho environment outlook report: Environment for national prosperity, Government Printeraseru.

Early, R., Bradley, B.A., Dukes, J.S., Lawler, J.J., Olden, J.D., Blumenthal, D.M. et al. 2016, 'Global threats from invasive alien species in the twenty-first century and national response capacities', Nature Communications 7, 124-185. https://doi. org/10.1038/ncomms12485

Fox, F.W. \& Norwood Young, M.E., 1982, Food from the veld: Edible wild plants of southern Africa, Delta Books, Craighall.

Hae, M.E., 2016, Invasive plant species in Lesotho's rangelands: Species characterization and potential control measures, United Nations University Land Restoration Training Programme [final project], viewed 12 March 2018, from http://www.unulrt.is/static/fellows/document/hae2016.pdf.

Henderson, L., 1989, 'Invasive alien woody plants of Natal and the north-eastern Orange Free State', Bothalia 19(2), 237-261. https://doi.org/10.4102/abc. v19i2.966

Henderson, L., 1991a, 'Invasive alien woody plants of the Orange Free State', Bothalia 21(1), 73-89. https://doi.org/10.4102/abc.v21i1.868

Henderson, L., 1991b, 'Invasive alien woody plants of the Northern Cape', Bothalia 21(2), 177-189. https://doi.org/10.4102/abc.v21i2.885

Henderson, L., 1992, 'Invasive alien woody plants of the Eastern Cape', Bothalia 22(1) 119-143. https://doi.org/10.4102/abc.v22i1.830

Henderson, L., 1995, Plant invaders of Southern Africa. Plant Protection Research Institute Handbook No. 5, Agricultural Research Council, Pretoria.

Henderson, L., 1998a, 'Invasive alien woody plants of southern and southwestern Cape region, South Africa', Bothalia 28(1), 91-112. https://doi.org/10.4102/abc. v28i1.624

Henderson, L., 1998b, 'Southern African Plant Invaders Atlas (SAPIA)', Applied Plant Sciences 12, 31-32.

Henderson, L., 2001, Alien Weed and Invasive Plants, a complete guide to declared weeds and invaders in South Africa, Agricultural Research Council, Pretoria.

Henderson, L., 2007, Invasive, naturalised and casual plants in southern Africa: A summary based on the Southern African Plant Invaders Atlas (SAPIA)', Bothalia 37(2). https://doi.org/10.4102/abc.v37i2.322

IUCN, 2017, Invasive species and climate change, viewed 15 May 2018, from https:// www.iucn.org/resources/issues-briefs/invasive-alien-species-and-climatechange

Jacot Guillarmod, A., 1971, Flora of Lesotho, Cramer, Lehre.

Khan, M.A.S.A., Sultana, F., Rahman, M.D.H., Roy, B. \& Anik, S.I., 2011, 'Status and ethno-medicinal usage of invasive plants in traditional health care practices: A 649-658. https://doi.org/10.1007/s11676-011-0174-8

Kobisi, K., 2005, Preliminary checklist of the plants of Lesotho, Southern African Botanical Diversity Network Report No. 34, SABONET, Pretoria, ISBN: 1-91979567-7.

Kotze, J.D.F., Beukes, B.H., Van den Berg, E.C. \& Newby, T.S., 2010, National invasive alien plant survey, Report Number: GW/A/2010/21, Agricultural Research Council, Pretoria.

Kuete, V. (ed.), 2014, 'Chapter 22: Physical, hematological, and histopathological signs of toxicity induced by African medicinal plants', in Toxicological survey of African medicinal plants, pp. 632-652, Elsevier, Amsterdam.

Lesotho Government, 2001, Environment Act, 2001, Government Gazette Extraordinary, Government Printer, Maseru.

Lesotho (Basutuland) Government, 1959, Laws of Lerotholi (revised), Morija Sesotho Book Depot, Morija.

Maema, L.P., Potgieter, M. \& Mahlo, S.M., 2016, 'Invasive alien plant species used for the treatment of various diseases in Limpopo province, South Africa', African Journal of Traditional, Complementary and Alternative Medicine 13(4), 223-231. https://doi.org/10.21010/ajtcam.v13i4.29

Maliehe, E.B., 1997, Medicinal Plants and Herbs of Lesotho (in Sesotho), Mafeteng Development Project, Maseru.

Moffett, R., 2010, Sesotho plant and animal names and plants used by the Basotho, Sun Press, Bloemfontein.

Moteetee, A. \& Van Wyk, B-E., 2006, 'Sesotho names for edible plants (exotic and indigenous)', Bothalia 36(2), 25-32.

Moteetee, A. \& Van Wyk, B-E., 2007, 'The concept of 'musa-pelo and the medical use of shrubby legumes (Fabaceae) in Lesotho', Bothalia 37, 75-77.

Moteetee, A. \& Van Wyk, B-E., 2011, 'The medical ethnobotany of Lesotho: A review', Bothalia 41(1), 209-228. https://doi.org/10.4102/abc.v41i1.52

Moteetee, A. \& Seleteng Kose, L., 2017, 'A review of medicinal plants used by the Basotho for treatment of skin disorders: their phytochemical, antimicrobial, and anti-inflammatory potential', African Journal of Traditional Complementary and Alternative Medicine 14(5), 121-137.

Moteetee, A., Moffett, R.O. \& Seleteng-Kose, L., 2019, 'A review of the ethnobotany of the Basotho of Lesotho and the Free State Province of South Africa (South Sotho)', South African Journal of Botany 122, 21-56. https://doi.org/10.1016/j. sajb.2017.12.012

Mugumeri, E., Chatanga, P. \& Chakane, N., 2016a, 'Medicinal herbs used by HIVpositive people in Lesotho', African Journal of Traditional Complementary and Alternative Medicine 13(4), 123-131. https://doi.org/10.21010/ajtcam.v13i4.17 
Mugomeri, E., Chatanga, P., Raditladi, T., Makara, M. \& Tarirai, C., 2016b, 'Ethnobotanical study and conservation status of local medicinal plants: Towards a repository and monograph of herbal medicines in Lesotho', African Journal of a repository and monograph of herbal medicines in Lesotho', African Journal of
Traditional, Complementary and Alternative Medicine 13(1), 143-156. https:// doi.org/10.21010/ajtcam.v13i1.20

National Environmental Secretariat, 2000, Biodiversity in Lesotho, a country study Morija Printing Works, Lesotho.

National Environmental Secretariat, 2002, Lesotho second state of the environment report, National Environment Secretariat, Maseru, Lesotho, ISBN 99911-632-6-0.

National Environmental Secretariat, 2005, Invasive alien species in Lesotho: A status report, Morija Printing Works, Maseru.

National Environment Secretariat, 2007, Invasive Alien Species in Lesotho, Distribution Report, Morija Printing Works, Maseru.

National Strategy, 2014, viewed 29 April 2018, from http://invasives.org.za/ legislation/what-does-the-law-say\#national-strategy

Nel, J.L, Richardson, D.M., Rouget, M., Mgidi, T.N., Mdzeke, N., Le Maitre, D.C. et al, 2004, 'A proposed classification of invasive alien plant species in South Africa: Towards prioritizing species and areas for management action', South African Journal of Science 100, 53-64.

Peters, C.R., O'brien, E.M. \& Drummond, R.B., 1992, Edible wild plants of sub-Saharan Africa, Royal Botanic Gardens, Kew.

Phillips, E.P., 1917, 'A contribution to the flora of the Leribe Plateau and environs', Annals of the South African Museum 16, 1-379.

Pooley, E., 1998, A field guide to wild flowers of KwaZulu-Natal and the Eastern Regions, Natal Flora Publication Trust, Durban.

Paterson, I.D., Hoffmann, J.H., Klein, H., Mathenge, C.W., Neser, S. \& Zimmermann H.G., 2011, 'Biological control of Cactaceae in South Africa', African Entomology 19(2), 230-246. https://doi.org/10.4001/003.019.0221

POSA, 2012, Plants of Southern Africa: An online checklist, South African National Biodiversity Institute, viewed 18 March 2018, from http://newposa. sanbi.org

Pyšek, P., Richardson, D.M Rejmanek, M., Webster, G.L, Williamson, M. \& Kirschner, J., 2004, 'Alien plants in checklists and floras: towards better communication between taxonomists and ecologists', Taxon 53, 131-143. https://doi. org/10.2307/4135498

Rahman, M.D.H. \& Roy, B., 2014, 'Population structure and curative uses of invasive plants in and around the protected forests of Bangladesh: A means of utilization of potential invasive species', Journal of Ecosystems 2014, Article ID249807. https://doi.org/10.1155/2014/249807
Rouget, M., Reyers, B., Jonas, Z., Desmet, P., Driver, A., Maze, K. et al., 2004, South African National Spatial Biodiversity Assessment 2004: Technical report. Volume 1 Terrestrial component, South African National Biodiversity Institute, Pretoria.

Schwarz, A., Medeiros, I., Mouräo, C., Queiroz, F. \& Pflugmacher, S., 2010, 'Phytochemical and toxic analysis of an ethanol extract from Cereus jamacaru', Toxicology Letters 196. https://doi.org/10.1016/j.toxlet.2010.03.1089

Schmitz, M.O., 1982, Wild flowers of Lesotho, ESSA, Roma.

Seleteng-Kose, L., Moteetee, A. \& Van Vuuren, S., 2015, 'Ethnobotanical survey of medicinal plants used in the Maseru district of Lesotho', Journal of Ethnopharmacology 170, 184-200. https://doi.org/10.1016/j.jep.2015.04.047

Shackleton, C.M., McGarry, D., Fourie, S., Gambiza, J., Shackleton, S.E. \& Fabricius, C., 2007, 'Assessing the effects of invasive alien species on rural livelihoods: Case examples and a framework from South Africa', Human Ecology 35, 113-127. https://doi.org/10.1007/s10745-006-9095-0

Shale, T.L., Stirk, W.A. \& Van Staden, J., 1999, 'Screening of medicinal plants used in Lesotho for anti-bacterial and anti-inflammatory activity', Journal of Ethnopharmacology 67, 347-354.

Vilà, M., Espinar, R.L., Hejda, M., Hulme, P.E., Jasrošik, V., Maron, J.L. et al., 2011 'Ecological impacts of invasive alien plants: A meta-analysis of their effects on species, communities and ecosystems', Ecological Letters 14, 702-708. https:// doi.org/10.1111/j.1461-0248.2011.01628.x

Van Wilgen, B.W., Richardson, D.M., Le Maitre, D.C., Marais, C. \& Magadlela, D. 2001, 'The economic consequences of alien plant invasions: examples of impacts and approaches to sustainable management in South Africa', Environment, Development and Sustainability 3, 145-168.

Van Wyk, B-E. \& Gericke, N., 2000, People's plants: A guide to useful plants of southern Africa, Briza Publications, Pretoria.

Van Wyk, B-E., Van Oudshoorn, B. \& Gericke, N., 1997, Medicinal plants of South Africa, Briza Publications, Pretoria.

Van Wyk, B-E., Van Oudtshoorn, B. \& Gericke, N., 2009, Medicinal plants of South Africa, Briza Publications, Pretoria.

Watt, J.M. \& Breyer-Brandwijk, M.G., 1962, The medicinal and poisonous plants of Southern and Eastern Africa, Livingstone, Edinburgh.

Weber, E., Sun, S-G. \& Li, B., 2008, 'Invasive alien plants in China: Diversity and ecological insights', Biological Invasions 10(8), 1411-1429. https://doi. org/10.1007/s10530-008-9216-3

Zimmerman, H.G., Moran, V.C. \& Hoffman, J.H., 2004, 'Biological control in the management of invasive alien plants in South Africa, and the role of the Working for Water Programme', South African Journal of Science 100, 34-40. 